\title{
Golf Tourism Destination Management: Looking for a Sustainable Demand: The Case of Portugal
}

\author{
Fernando Completo ${ }^{1} \&$ Nuno Gustavo ${ }^{1}$ \\ ${ }^{1}$ Estoril Higher Institute for Tourism and Hotel Studies, Estoril, Portugal \\ Correspondence: Nuno Gustavo, Estoril Higher Institute for Tourism and Hotel Studies, Av. Condes de \\ Barcelona, 2769-510 Estoril, Portugal. E-mail: nuno.gustavo@eshte.pt
}

Received: December 10, 2013 Accepted: December 20, 2013 Online Published: February 25, 2014

doi:10.5539/jms.v4n1p142 URL: http://dx.doi.org/10.5539/jms.v4n1p142

\begin{abstract}
The research on the problem of golf is essentially limited to environmental issues, and socioeconomic and cultural ones are usually neglected. In southern European countries where tourism is mainly dependent on "sun \& sea", golf courses supply is becoming more and more relevant, considering its balance facing "sun \& sea" low seasons. However, these countries have a poor cultural identification with golf, despite its relevance to attract international tourism markets (Marckwick, 2000; Neirotti, 2005).

This paper presents a demand side approach of the phenomenon, framing golf and its dynamics as a business supported in two distinct demand profiles: international tourist golfers and local leisure golfers-. To develop this analysis we take and compare different statistical sources.

The paper takes Portugal, a main international golf tourism destination, as a case study in the context of the countries of southern Europe. The comparison of statistical data on supply and demand of golf in Portugal is the basis for a reflection on the golf demand development.
\end{abstract}

Keywords: golf, leisure, tourism, demand dynamics, sustainability, destination

\section{Golf: From Its Origins to a Leisure Practice}

The origins of golf, regardless of the place or places where it was played for the first time and all the discussions surrounding this matter, has always been associated to Scotland and the year 1522, when the Royal and Ancient Club of St. Andrews was founded (Ceron-Anaya, 2010:343), although "the first reference to the game in Scotland dates back to 1457 when the Scottish Parliament declared that golf was interfering with the defence of the realm practice of archery, declaring golf to be 'utterly cryit doun and nocht usit' (Brasch, 1972)" (Hudson \& Hudson, 2010:6).

The game gained recognition as a sport and social practice from the mid of the $16^{\text {th }}$ century even though at first it was quite limited to wealthier social classes. In Europe and Asia, golf was expanded through colonialism and Scottish and English immigrants. By the end of the $19^{\text {th }}$ century the sport was already known worldwide, except in the United States, where recognition arrived in the $20^{\text {th }}$ century. It was the Scottish John Reid who was responsible for the introduction and promotion of golf in the United States "Reid, a Scottish expatriate businessman, imported a few clubs and balls from Scotland and in 1888 set up a rudimentary three-hole golf course near to his house in Yonkers, New York. The players of this first course formed themselves into a club called St Andrew's (its name copied from its famous Scottish predecessor-complete with an apostrophe to differentiate it)" (Hudson \& Hudson, 2010:6).

Considering the different variants that were in the origin of the game, the establishment of rules was vital for the universalization of golf. Again St. Andrews is closely linked to golf, because it was in charge of setting its rules (Readman, 2003).

Nowadays golf is a global sport and a form of leisure: "and golf is now global; it's played in almost every kind of environment. A desert course in Arizona is totally unlike new courses cut through the rainforest in Malaysia to satisfy the demand of Japanese hospitality tourism. Urban courses surrounded by golfing communities evoke different impressions from golf resorts isolated amongst wetlands" (Perkins, 201:314). 
Golf is played in circuits which are previously defined and that given the nature and features of the game differ in the area and landscape they are set in, which is a key element in attracting golfers and/or tourists. According to Standeven and De Knop (1999:60), 'the experience of place is a key component of the sport tourism experience'. Not only does the separate sphere of tourism involve people being attracted to destinations with distinctive characteristics and qualities, but sport also requires specific spatially located resources (Bull, 2005:25).

In its "official" version, a golf course has eighteen holes (in an area of approximately $6 \mathrm{~km}$ long) with different areas of game, such as tee, fairway, rough and green. These areas are alternated and have different obstacles, like lakes, bunkers or trees, so that each hole in particular and each course as a whole, have a unique geometry. "The diverse scenery in which golf is played not only forms a perceptual backdrop to the round but also affects on the design of the course" (Perkins, 2010:314). Thus the uniqueness of a golf course lies on the one hand on its landscape setting and on the other on the architectural organization of the different elements of the game together with the natural and artificial obstacles.

\section{Golf: From the Game to the Business}

Given the nature and features of the game, building a golf course requires a huge investment that implies a significant number of resources, a situation which results in a wide range of direct, indirect and induced effects on the economic activity. This fact is expressed in a set of business and revenues arising directly from the game - core industries - golf facility operations (green fees, membership dues, food \& beverage, lessons rentals), golf course capital investment (irrigation installation, new course/course renovations, infrastructure improvements, etc.), media, tournaments associations \& charities (television, player endorsements, etc.) and golf supplies - and of course - (soft goods, hard goods, apparel, books/magazines). On the other hand there are also two other areas of satellite businesses to which golf is closely linked - enable industries: hospitality/tourism (air travel, lodging, car rental, etc.) and real estate (real estate premium, related residential construction) (KPMG 2008a, SRI International 2008 in Hudson \& Hudson, 2010:11). Still considering the economic aspects, a golf course is a natural resource, unlike other leisure and tourism infrastructures such as a hotel, a SPA or a gym, so its maintenance is demanding and necessarily daily, regardless of its occupancy rate. Economically and financially speaking this situation is quite demanding because the costs of such maintenance are mainly fixed.

In countries where golf is a nationally relevant sport, this investment is often supported by the State. This situation creates a special kind of condition and ensures a unique and free access to the practice of this sport whereas in countries where the number of golfers is not very significant the investment is usually private and set up around a group of parallel activities such as real estate and tourism. This is proven by the significant increase in the last decades in the countries of southern Europe: "most of the impact of the golf industry in Portugal, Spain, France and Italy reflects golf enthusiasts travelling there for golf holidays and their purchase of holiday homes built as part of golf communities and golf resorts" (Hudson \& Hudson, 2010:10).

\section{Golf as a Tourism Product}

Nowadays the relationship between golf and tourism is evident and represents a unique market with its own features to which access is limited to golfers (i.e., those who practice the sport). In fact, this condition is common to all private courses where access is authorized only to holders of valid handicap, something that implies the player's federation.

However the number of golfers has increased significantly worldwide, as well as the number of golf courses around the world. In Europe alone golf is the cause for more than a million trips per year and this number is expected to double by the year 2015 (MEI, 2007).

The excellence of the golf course is crucial for the affirmation of golf as a tourism destination, as well as the private investment and the necessary weather conditions. "Golf has been systematically imported into many hot climate destinations as a tourism development strategy in recent years (Priestley, 1995; Bartoluci \& Cavlek, 2000)" (Higham \& Hinch, 2009:179). This circumstance arises from the nature and spirit of the game, since the challenge is essentially set on the level of the relationship/interaction player/course, even though golf is preferably a group sport. The higher the number of golf courses available in a destination, greater its capacity to attract and retain golf tourists. During their stay, golf tourists like to play in different courses, even they remain in the same accommodation. The "packages" include: flight, transfers, green fees, access to the practice areas (driving range, putting green, short game area), golf teacher, accommodation, food \& beverage (tourism packages of $7 \& 5$ - seven nights and five green fees - or $3 \& 2$ - three nights and two green fees). 
Given its unique features, golf is not only valuable as a tourism product, but it also diversifies the offer of a tourism destination and is relevant in helping to mitigate the seasonality phenomenon in line with the remain tourism products. "[T]he relationship between sport and tourism seasons can be actively influenced with destination management goals in mind. Thus changes to the sport product mix, the use of sports events and the development of niche sport tourism markets are among some of the responses that destination organizations may pursue in an attempt to manage seasonal travel flows" (Higham, 2005:157). The potential integration with other tourism products, namely "Sun and Sea", gives it a unique additional attribute of projection and affirmation (Readman, 2003).

Golf is also assuming a major role in the context of the Meetings Industry, given the networking features of the game:

"Over the last fifteen years golf and business have become inseparable. Golf has become recognized as a valuable networking tool. Executives from a diverse array of industries would meet at country clubs, play a round of golf together and gradually realized the possibility of doing business right there on the course (Dobrian, 2002). For some, golf is a way to create stronger relationships with clients or coworkers due to the leisurely pace of the sport" (Nice, 2004:37).

This is particularly relevant considering that the development of tourism activities has been consolidated both quantitatively and qualitatively. According with United Nation World Tourism Organization (UNWTO) in 1950 the 5 main world destinations represented $71 \%$ of all tourist international arrivals and today this number does not go beyond $40 \%$ and includes destinations from all continents and not only the Western world (UNWTO, 2001).

Given this scenario, marked by a tourist demand not only increasingly more significant and heterogeneous but also more experienced and demanding, it becomes urgent for these tourism destinations to seek new strategic models of competition as well as new factors for differentiation. The challenge is not only to attract new tourists, but also to retain them. Until some time ago the uniqueness of the heritage of a place was a sufficient factor of attraction and the model of competition laid on the enhancement of such heritage through the development and improvement of its secondary features (accessibility, support infrastructures, accommodation, etc.). Currently this condition itself has proved insufficient and represents a mere premise of a new competitive environment between destinations.

New paradigms and sustainable competition factors are being defined in an increasingly globalized world where by virtue of the technological development every destination is just a click or a few flight hours away. Sustainability and differentiation of tourism destinations are central issues in a ever more mature and global tourism market. The diversification and competitiveness of tourism products are core development vectors in the reinvention of tourism supply in order to give new competition arguments and ensure a mix of supply that mitigates as much as possible the adversities associated to a growing global competition (Knowles et al., 2004).

\section{Golf Demand and Golf Destinations: Issues and Dimensions}

The golf practice, while a sport activity, works out in the cultural and symbolic social universe and goes beyond of the game, making it an important subject of reflection, discussion and academic research. Golf related issues, such as land planning, environmental management, social conflicts with host communities; consumption and elitism are frequent and part of public opinion discussion and concern. Moreover, the literature review indicates that there are within the scientific research a considerable number of studies that reflect those themes (Perkins, 2010; Nauright \& Wheeler, 2006).

Briassoulis (2010), in its academic paper entitled "Sorry golfers, This is not your spot!: Exploring public opposition to golf development", analyse a set of relevant studies on golf's conflicting issues. The main topics are the local communities, the environment and the golf operators. As an answer to these different dimensions that affect the sustainability of Golf, Woodside (2010) suggests that the key for sustainable golf destinations is founded in a complex and dynamic model. This model, works out as system resulting from the interaction between three interdependent golf dimensions: territorial development, cultural community and golf industry.

In the context of golf practice, the dimension of territorial development is a topic that regularly comes to public as a main pejorative factor. Factors such as water management, soil pollution, energy consumption, changing landscape, are abundantly cited as inducing reactive towards golf development (Woodipper \& Jones, 2000; Minolia \& Smith, 2011; Hammond \& Hudson, 2007).

According to Woodside and following the mentioned model (2010), golf can play an important role in the process of environment qualification, in the sustainable economic development and in the increasing of the quality of life of the host communities. This assumption is also supported by the research work done by Videira 
et al. (2006). This study focuses in the Algarve region, the main Portuguese tourism destination. Despite being well-known by their sunny beaches, the Algarve is also internationally recognised as a golf tourism destination, offering more than 40 golf courses. The paper presents a sustainability assessment framework and the results from its application to the Algarve's golf courses. It was concluded that the position of the existing golf courses, concerning to their environmental and economic sustainability, could be improved if management tools were implemented by many of the golf clubs.

In the field of social responsibility of golf, some NGO's are working to develop more sustainable golf processes. They are developing environmental voluntary programs focused on the application of eco-certification for golf courses, especially those located in ecologically sensitive areas (Minola \& Smith, 2011; Potoski \& Prakash, 2012).

Concerning to the cultural community issues and golf there is a widespread interpretation that associates golf with social elite. Golf is historically consecrated as a sport practice exclusive of high social and economic classes, and so, has found many obstacles to claim itself as a popular sport (Vamplew, 2010). This dimension is also a determining factor to realize the level of integration/rejection that golf assumes in social context. The educational process is appointed out by Shao et al. (2010), as a key variable for the development and sustainability of the golf. This research suggests the training of golf, interpreted as an educational strategy, is a critical issue not only to democratize the access to the practice, as also to ensure the quantitative and qualitative expansion of golf market (facilities, supplies, etc.), gaining fans and building a favourable a social and cultural identity. The process of golf democratization through an educational strategy is a key issue for its promotion in host communities, ensuring the expansion of the practice, especially as a sport and leisure activity.

The Golf Industry is structured in a binomial market. On one hand we have golf as a leisure sport, and so as a social cultural sport practice of the host community. On the other hand, golf is associated with tourism activity and so dependent on tourism international markets, mostly from the North to the South of Europe, and with a limited connection to the local community (Bull, 2005; Higham, 2005; Moital et al., 2013).

The theoretical background pointed out, as well as the processes and frameworks mentioned, are part of the model of dynamic systems, reflecting the "issues and criticisms concerning golf, tourism, and the environment and considers how golf-tourism-environment relationships might achieve economic wellbeing for the region while avoiding vicious cycles of destruction to local environments and the quality of life of residents place" (Woodside, 2010: 343).

\section{Case Study - Golf in the Southern Europe Destination: The Case of Portugal}

\subsection{Methods}

Considering that this case study focuses in the reality of golf in Portugal and especially in the sustainability of this activity, in particular in the perspective of the destination, it was essential to assess the size of the supply and demand of the golf market, as well as the specific features of each of these dimensions.

To gather this information we turned to different secondary reference sources regarding data concerning golf supply and demand. As for the demand, the main sources of information of the data presented here are monitoring reports of KPMG consultant.

KPMG together with the European Golf Association (EGA) performs a regular monitoring of golf worldwide which results in different reports. Having as reference the results of such reports, new additional indicators were produced and analyzed, considering the southern European countries and especially Portugal. To complement these statistical sources we also used the official activity reports of the Portuguese Golf Association.

\subsection{Data Collection}

In 2011, according to KPMG report (2012) "Golf Participation in Europe 2011", elaborated on the basis of information provided by the various European Golf Federations, the European Golf Association and Eurostat, there were a total of 4.389 .740 million golfers in Europe and a supply of 6.470 golf courses. The golf supply and demand was distributed by different European countries according to the table below: 
Table 1. Local golf participation rate in Europe sorted by local players in 2011

\begin{tabular}{|c|c|c|c|c|c|c|}
\hline Country & $\begin{array}{l}\text { Local } \\
\text { Players } \\
\text { (2011) } \\
\end{array}$ & $\begin{array}{l}\% \text { Change } \\
\text { from } 2010\end{array}$ & $\begin{array}{l}\text { Courses } \\
(2011)\end{array}$ & $\begin{array}{l}\% \text { Change } \\
\text { from } 2010\end{array}$ & $\begin{array}{l}\text { Participation } \\
\text { rate }\end{array}$ & $\begin{array}{l}\text { Population per } \\
\text { golf course }\end{array}$ \\
\hline UK \& Ireland* & $1,326,663$ & $-3.1 \%$ & 2,989 & $-0.1 \%$ & $1.98 \%$ & 22,388 \\
\hline Germany & 610,104 & $1.8 \%$ & 708 & $1.1 \%$ & $0.75 \%$ & 115,468 \\
\hline Sweden & 491,401 & $-4.1 \%$ & 454 & $-0.4 \%$ & $5.22 \%$ & 20,739 \\
\hline France & 407,530 & $-0.7 \%$ & 578 & $0.7 \%$ & $0.65 \%$ & 109,232 \\
\hline Netherlands & 351,640 & $2.2 \%$ & 201 & $4.7 \%$ & $2.11 \%$ & 82,865 \\
\hline Spain & 328,495 & $-2.9 \%$ & 349 & $1.2 \%$ & $0.71 \%$ & 132,243 \\
\hline Denmark & 151,185 & $-0.9 \%$ & 181 & $0.6 \%$ & $2.72 \%$ & 30,722 \\
\hline Finland & 142,184 & $3.6 \%$ & 126 & $0.0 \%$ & $2.65 \%$ & 42,661 \\
\hline Norway & 121,736 & $-2.7 \%$ & 173 & $-0.6 \%$ & $2.47 \%$ & 28,441 \\
\hline Austria & 104,490 & $0.0 \%$ & 149 & $-1.3 \%$ & $1.24 \%$ & 56,404 \\
\hline Italy & 100,548 & $0.2 \%$ & 273 & $1.5 \%$ & $0.17 \%$ & 222,075 \\
\hline Switzerland & 79,843 & $4.1 \%$ & 94 & $0.0 \%$ & $1.01 \%$ & 83,686 \\
\hline Belgium & 55,206 & $3.8 \%$ & 79 & $0.0 \%$ & $0.50 \%$ & 138,629 \\
\hline Czech Rep. & 49,849 & $7.6 \%$ & 89 & $8.5 \%$ & $0.47 \%$ & 118,346 \\
\hline Iceland & 16,054 & $3.4 \%$ & 66 & $0.0 \%$ & $5.04 \%$ & 4,825 \\
\hline Portugal & 14,656 & $0.8 \%$ & 88 & $4.8 \%$ & $0.14 \%$ & 120,875 \\
\hline Slovenia & 8,495 & $7.5 \%$ & 13 & $8.3 \%$ & $0.41 \%$ & 157,707 \\
\hline Slovakia & 6,732 & $12.2 \%$ & 13 & $8.3 \%$ & $0.12 \%$ & 418,098 \\
\hline Turkey & 5,649 & $2.0 \%$ & 19 & $5.6 \%$ & $0.01 \%$ & $3,880,157$ \\
\hline Luxembourg & 4,023 & $-2.1 \%$ & 6 & $0.0 \%$ & $0.79 \%$ & 85,307 \\
\hline Poland & 2,750 & $0.0 \%$ & 29 & $20.8 \%$ & $0.01 \%$ & $1,317,243$ \\
\hline Estonia & 2,088 & $6.8 \%$ & 8 & $14.3 \%$ & $0.16 \%$ & 167,524 \\
\hline Hungary & 2,028 & $-19.2 \%$ & 13 & $0.0 \%$ & $0.02 \%$ & 768,132 \\
\hline Greece & 1,780 & $33.3 \%$ & 8 & $14.3 \%$ & $0.02 \%$ & $1,413,736$ \\
\hline Cyprus & 1,227 & $-9.2 \%$ & 10 & $11.1 \%$ & $0.15 \%$ & 80,444 \\
\hline Latvia & 900 & $16.1 \%$ & 3 & $0.0 \%$ & $0.04 \%$ & 743,214 \\
\hline Romania** & 551 & $0.0 \%$ & 4 & $0.0 \%$ & $0.00 \%$ & $5,353,454$ \\
\hline Croatia** & 550 & $0.0 \%$ & 3 & $0.0 \%$ & $0.01 \%$ & $1,470,712$ \\
\hline Bulgaria & 535 & $222.3 \%$ & 6 & $50.0 \%$ & $0.01 \%$ & $1,250,811$ \\
\hline Serbia & 440 & $46.7 \%$ & 2 & $100.0 \%$ & $0.01 \%$ & $3,638,098$ \\
\hline Lithuania & 408 & $-5.1 \%$ & 6 & $20.0 \%$ & $0.01 \%$ & 540,767 \\
\hline Europe total & $4,389,740$ & $-1.0 \%$ & 6,740 & $0.7 \%$ & $0.73 \%$ & 88,823 \\
\hline
\end{tabular}

Source: European Golf Association, local golf federations and Eurostat, with KPMG elaboration.

According to this information, golf is a particularly relevant phenomenon in north and central Europe, the regions where there is a larger percentage of players and golf courses.

On the other hand, in terms of participation and according to male, female and youth categories, the distribution is as follows:

Table 2. Local golf players by age, gender and country in 2011 in percentage - sorted by youth participation

\begin{tabular}{llll}
\hline Country & Male (\%) & Female (\%) & Junior (\%) \\
\hline Turkey & 34 & 14 & 52 \\
Serbia & 55 & 11 & 34 \\
Greece & 62 & 13 & 25 \\
Romania* & 61 & 15 & 24 \\
Latvia & 66 & 11 & 23 \\
Bulgaria & 70 & 11 & 19 \\
Lithuania & 69 & 15 & 17 \\
Czech Rep. & 59 & 27 & 15 \\
Iceland & 62 & 25 & 14 \\
\hline
\end{tabular}




\begin{tabular}{llll}
\hline Slovenia & 58 & 28 & 14 \\
Finland & 60 & 27 & 13 \\
Luxembourg & 57 & 29 & 13 \\
Slovakia & 61 & 26 & 13 \\
Belgium & 59 & 29 & 12 \\
Italy & 64 & 24 & 12 \\
France & 63 & 26 & 11 \\
Norway & 66 & 24 & 11 \\
Sweden & 62 & 27 & 11 \\
Austria & 55 & 35 & 10 \\
Hungary & 71 & 19 & 10 \\
UK \& Ireland & 75 & 15 & 10 \\
Estonia & 67 & 24 & 9 \\
Germany & 56 & 35 & 9 \\
Portugal & $\mathbf{7 3}$ & $\mathbf{1 9}$ & $\mathbf{9}$ \\
Switzerland & 58 & 33 & 9 \\
Denmark & 63 & 29 & 8 \\
Cyprus & 70 & 24 & 6 \\
Poland & 80 & 15 & 6 \\
Netherlands & 64 & 31 & 5 \\
Spain & 67 & 29 & 5 \\
Croatia* & 86 & 14 & 0 \\
\hline
\end{tabular}

Data:*2010 data. No data available on 2011.

Source: EGA and local federations, with KPMG elaboration.

\subsection{Data Analysis}

Golf in Portugal assumes a relevant condition. This reality is reflected not by the dimension of domestic demand, i.e. as a cultural and sport leisure activity of the population residing in Portugal, considering that the country has only 14.198 (2013) affiliated players (24.1\% of whom are foreign but with second home in Portugal), i.e., $0.14 \%$ of the population participation, but mainly by the size of the supply, given the territorial dimension of the country and the economic and social impact of this sport.

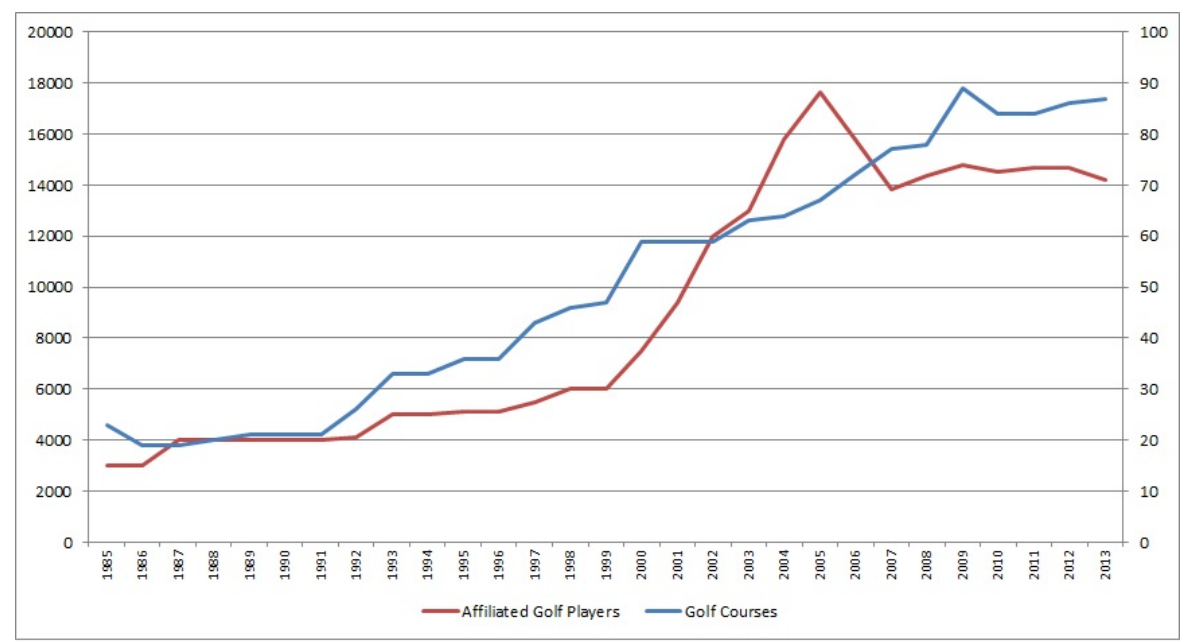

Figure 1. Affiliated golf players vs. golf courses - evolution in Portugal

Source: EGA (European Golf Association), 2013.

Portugal currently has a significant supply of about 88 golf courses (EGA, 2013). On the other hand, the economic and social impact of golf in Portugal stems essentially from two vectors: tourism and real estate. Tourism and real estate as satellite activities of golf (Hudson \& Hudson, 2010) create a significant set of indirect 
and induced jobs. Tourism has an indirect influence on property development. The increase in tourism increases the number of golf courses, which in turn increases property development, which in turn increases the number of golf courses (Woodside, 2010:345). Notice that according to KPMG and Oxford Economics (2008) in golf destinations with Portugal's features, golf real estate represents about $70 \%$ of the business, golf tourism $15 \%$ and golf core business (tournaments, golf facilities, capital investment, golf supplies) only $15 \%$ of the volume of business associated to the sector.

On the other hand, regarding the demand, it is noteworthy that golf is considered one of the top ten strategic products of the national strategic plan for Portuguese tourism. Due to its geographic and weather conditions, Portugal is recognized internationally as a sun and sea tourism destination, the main tourism product of the country. However Portugal is also currently recognized as a golf tourism destination (Hudson \& Hudson, 2010). A set of events of large dimension and worldwide projection such as the Expo98, Euro 2004, World Sailing Cup-Olympic classes 2007, Volvo Ocean Race 2012 stopover) have given prominence to Portugal as a tourism as well as a golf destination. Nowadays in Portugal, for pa considerable number of elite athletes present at these kind of events.

Due to these circumstances, today, golf is strategically taken as a core activity for tourism development in Portugal and it has become associated to the image and brand of Portugal at an international level, highlighting the country potentialities, including the country excellent weather and hospitality conditions.

The importance of golf in the Portuguese tourism strategic plan is due not only to the potential in terms of golf courses supply but also for its strategic significance in a sustainability and destination management context. Considering the seasonal nature of tourism in Portugal given the structural weight of sun and sea tourism product (especially in summer months-June to September), golf has been used as a mitigating product for this situation, since the high seasons in the international tourism market are the months of March, April and May and then September, October and November, when golf courses in north European markets (United Kingdom and Scandinavia) are closed.

This is particularly evident in the Algarve, the main tourism region of Portugal, well known for its beaches and where $50 \%$ of golf courses supply in Portugal is concentrated. On the other hand, the argument of the golf course in the real estate market was used as a differentiating factor in house sales, not only for golf foreign clients residential tourism (also considered as one of the Portuguese tourism top ten strategic products) but also for the population residing in Portugal (first home) (MEI, 2007).

Proof of this condition is the fact that Portugal currently has a chronic discrepancy between golf supply and demand, typical of various southern European countries (Italy, Turkey, Greece and Croatia). However this situation is particularly significant in Portugal since in a ratio golf course/affiliated golfers, Portugal is on the $25^{\text {th }}$ position in a total of 31 countries, with a 167 ratio of resident golfers per course. This is a very low participation rate. From the business point of view, to provide some stability for operators, it is estimated that the number of resident golfers per course would reach a minimum of 1.850 (Hatami, 2013). According with this ratio Portugal should have 162.800 golf players against the actual 14.656 golfers.

This situation is even more significant if we consider that Portugal has a supply of 88 golf courses and none is public. In Portugal all golf courses are private. There are only two small public infrastructures: a driving range in Lisbon (at the National Stadium Sport Complex) and a Picth \& Put facility in Cantanhede (centre of Portugal).

Table 3. Golf Supply sorted by local players per golf course in Europe per country

\begin{tabular}{llllllll}
\hline Rank & Country & $\begin{array}{l}\text { Local Players } \\
\text { per golf course }\end{array}$ & Golf Courses & Rank & Country & $\begin{array}{l}\text { Local Players } \\
\text { per golf course }\end{array}$ & $\begin{array}{l}\text { Golf } \\
\text { Courses }\end{array}$ \\
\hline 1 & Netherlands & 1749 & 201 & 17 & Italy & 368 & 273 \\
2 & Finland & 1128 & 126 & 18 & Latvia & 300 & 3 \\
3 & Sweden & 1082 & 454 & 19 & Turkey & 297 & 19 \\
4 & Spain & 941 & 349 & 20 & Estonia & 261 & 8 \\
5 & Germany & 862 & 708 & 21 & Iceland & 243 & 66 \\
6 & Switzerland & 849 & 94 & 22 & Greece & 223 & 8 \\
7 & Denmark & 835 & 181 & 23 & Serbia & 220 & 2 \\
8 & France & 705 & 578 & 24 & Croatia** & 183 & 3 \\
9 & Norway & 704 & 173 & 25 & Portugal & 167 & 88 \\
10 & Austria & 701 & 149 & 26 & Hungary & 156 & 13 \\
\hline
\end{tabular}




\begin{tabular}{llllllll}
\hline 11 & Belgium & 699 & 79 & 27 & Romania** & 138 & 4 \\
12 & Luxembourg & 671 & 6 & 28 & Cyprus & 123 & 10 \\
13 & Slovenia & 653 & 13 & 29 & Poland & 95 & 29 \\
14 & Czech Rep. & 560 & 89 & 30 & Bulgaria & 89 & 6 \\
15 & Slovakia & 518 & 13 & 31 & Lithuania & 68 & 6 \\
16 & UK \& Ireland* & 444 & 2989 & & & & \\
\hline
\end{tabular}

Source: European Golf Association, local golf federations and Eurostat, with author elaboration.

This discrepancy is essentially due to the fact that the main client of the Portuguese golf courses in not eminently resident but comes from the golf tourism, i.e., from international markets where supply and demand are significantly developed despite the weather limitations of these countries (northern Europe and Scandinavia). This circumstance reflects a distinctive reality: the fact that golf is not part of the sociological, cultural and sport matrix of the Portuguese population despite the supply of golf courses in Portugal. This situation is proven by the low participation of the Portuguese population as opposed to a well developed supply that represents a 120.875 ratio of residents per golf course (KPMG, 2012).

The explanation of this fact contains three types of arguments which are transversal to sport activity and define social representations about golf that exist in Portugal which should be clarified. In fact, this type of social identity prejudicial assumption also occurred with surf and still exists with sailing and is instituted through ideological representation, educational dimension and communicational dynamics.

Concerning the ideological representation and even though the paradigm is starting to change, golf is still seen as a social and recreational activity of the privileged rather than a mere sport. That's one of the reasons way there's no public golf facilities in Portugal.

The assumption that golf is a sport of the privileged focuses on the one hand on the collective perception that golf is associated with a principle of privacy and limited access, inhibited to all those who are not part of the "clan". This idea also associates golf to a profile from a high social class and economic condition, as well as an activity whose equipment and practice are significantly expensive.

In the last few years, the market players have been trying to change this prototype, considering a set of strategic measures which have been taken to democratize the access to golf in order to promote and capture new golfers.

The persistent imbalance between supply and demand has been particularly relevant in the past few years, leading to the collapse of prices of green fees as shown by the different agreements between various golf clubs, the Portuguese Golf Federation (FPG) and CNIG (National Council of the Industry of Golf) in order to offer promotional fares to their associates (green fees from $15 €$ ). The fact that the international market of golf tourism is limited to only four months per year since in the remaining periods golfers are able to use golf courses in their own countries, puts significant pressure on the management of golf courses in Portugal given that the other eight months of the year there is not a national demand sufficient to sustain the supply. Evidence of this reality is the price of an annual golf subscription: in 2005 it costs about $1.000 €$ in 2012 the average price in near $600 €$ (CNIG, 2006 and 2013).

Golf is also associated to regional planning and environmental balance. This is a critical dimension to reach a complex sustainable model of golf tourism (Woodside, 2010). Golf is usually closely linked to environmental impact and is classified as pollutant. Without discarding the possible effects in the dynamics of landscape, water consumption and pressure caused by the use of fertilizers, it should be noted that there has been an extensive technical and scientific effort made in the last decade to produce zero environmental impact in the process of construction and maintenance of golf courses. The rationalization and in some cases the reuse of water, soil drainage to avoid root rot and an effective and efficient environmental management are factors that have been successfully introduced in the qualification process and environmental responsibility of the golf spaces. Besides, the process of implementation and construction of golf courses is subject to regulation (DL 96/2000, $3^{\text {rd }}$ May) which specifies the need for environmental impact evaluation regarding "new 18 hole courses or above 45 ha must be subjected to environmental impact evaluation processes if they are located in sensitive areas".

The educational dimension assumes a very important role in the process of promotion and democratization of golf and has a strategic role in the operation of capturing new golfers, especially amongst youth. In order for this to happen, it is necessary to mitigate the existing indifference on the level of the educational process, increasing awareness and training campaigns as part of federation and clubs actions as well as school sports. 
Despite the evidence of the situation this is a neglected reality in Portugal as we can see by the low number of young players affiliated in Portugal: only $9 \%$ of the total golfers residing in Portugal are young golfers, showing that there has not been a sufficient effort made to create new demand on a national level (KPMG, 2011). On the other hand, the supply and demand change rates registered in past year show the aggravation of this situation, since supply is increasing faster $(4,8 \%)$ than domestic demand $(0,8 \%)$.

Communicational dynamics should also be reinforced, since there is a need to increase the national promotion networks of golf. More people should be taken to the greens, as tournaments participants or spectators, so as to mitigate the prejudice against golf. However his can only be accomplished if it is possible to standardize the idea of golf. In fact it was the media and the increasing of information and images about surf that have turned the spotlight on this sport in Portugal, increasing the demand and the growth of professional athletes, new surf schools and a wide social acceptance.

Golf has all the conditions to go the same way, whether as sport or leisure. It is therefore important to promote it in a large scale. Knowing that tourism activity is of great economic importance, we cannot ignore the importance of the leisure dimension to the direct and indirect sustainability of golf.

\section{Conclusions}

In a scenario that is increasingly competitive, the diversification of tourism products and the investment in new segments and market niches assumes an increasingly relevant role in the sustainability perspective of tourism destinations, to increase potential demand and decrease the dependence on certain markets (Pedro, 2006).

Nowadays golf is a real motivation for travelling and an attractive business which by nature mobilizes a wide set of indirect and induced effects, especially tourism and real estate. Because of its growing relevance, golf is increasingly seen by the different players of the tourism industry as a relevant tourism product.

Golf is clearly rising, driven by new international sport heroes that attracted the media and the sponsor's attention:

Ever since Tiger Woods first won the Masters' in 1997, golf has got sexier. No longer largely the preserve of the privileged, it's become a trendy sport with an appeal across generations, genders and cultures. The Ryder Cup is now watched on television by around a billion people worldwide. Compare that to the mere 260 million who watched the 2006 Soccer World Cup. TV has helped create golf icons across the globe with increasing tournament coverage and advertising endorsement (Hudson \& Hudson, 2010: 3).

The growing number of golfers on an international level, combined with the fact that it is an increasingly tourism phenomenon because the tourist has the option to choose his/her destination according to the new challenges of the game offered by weather and nature of each course, gives high potential of growth to this product. It is expected that in Europe alone golf will prompt about two million trips in 2005 (MEI, 2007).

However given the features and specificity on what concerns the ability and culture regarding this sport (demanding constant practice), the international supply and demand distribution (with special emphasis in Europe) and the business management characteristics (prevailing a structure of almost $100 \%$ fixed costs), golf must be understood as not only a touristic activity, but mainly as leisure which is in fact on its origin.

In the perspective of a destination, the development of golf as a tourism activity is hardly sustainable, considering the fact that in this scenario it is highly seasonal. Golf's sustainability should be strategically considered by reference to the leisure market, given its economic and financial needs.

Under these circumstances, the future of golf in Portugal should be clearly reworked considering on the one hand the balance between the supply of golf courses and professional golfers, and on the other its excessive dependence in terms of development models of its satellite businesses (tourism and real estate). In this sense it is possible to consider two possible scenarios for the development of golf in Portugal, considering its necessary sustainability:

- PORTUGAL AS AN INTERNATIONAL GOLF SPOT: golf as an eminently tourist activity: in this case supply must necessarily be reworked since it is clearly excessive given the demand of golf in Portugal.

This situation arises from the fact that such demand comes from foreign markets who do not reside in the country, and that it is highly seasonal (and limited to four months per year). If on the one hand golf as a tourism product has a relevant role in the perspective of the sustainability of Portugal tourism destination complemented with the sun and sea tourism product, on the other the dimension of the market, insufficient to ensure economic and financial sustainability of the golf courses, should be taken into consideration. 
Alongside the supply of golf courses and other tourism supply, international demand is particularly relevant in the Algarve and Lisbon (including Estoril and Costa Azul). The Algarve concentrates 45,1\% of the national golf courses and Lisbon 27,4\% (Tourism of Portugal, 2008).

This strategic choice is justified by the fact that international golfers choose to play in different courses during their stay, a crucial fact for the concentration of supply and its development in specific regions (Tourism Observatory of Lisbon, 2010). So golf supply in Portugal should be organized not on a destination point of view, but as Golf Spots, with special attention to the regions of the Algarve and Lisbon (Estoril and Costa Azul).

Of course this option implies a significant reduction of the present golf courses supply, a situation that may lead to a set of negative impacts on different levels in a short term period: economic, social and environmental.

- GOLF AS A PORTUGUESE LEISURE SPORT: golf as an eminently leisure activity: besides the tourism dimension identified in the scenario above, golf tends to be assumed as a leisure activity in the Portuguese cultural and sport universe. This demands the definition of a strategic plan of development for golf, regarding both demand and supply. In this way, it is possible to turn viable the existing supply and ensure Portugal as a competitive and sustainable golf destination on economic and social levels.

The first specific action axis here presented - the development of demand-has to be performed having as a central point the cultural identification of the Portuguese people with golf (Neirotti, 2005). For this to happen the definition of a line of action aiming at the definition of an integrated public-private training model (associating golf courses and training infrastructures, golf professionals, etc.) is vital, and the inclusion and stimulation of golf in education plans. On the other hand, it is still important to develop a line of action regarding the communication issues with natural resources. The compromise should be centred in a regular promotional plans and not just individual events of international importance and coverage.

On the other hand it is also noteworthy, within the national strategic plan for golf mentioned above, the need for public-private investments in the development of golf equipment and resources, since "Golf is a technical sport requiring an extensive body of competencies before career opportunities can be fully exploited. Acquisition of such knowledge is often cost prohibitive for members of minority groups, which subsequently excludes minorities from active participation and career exploration." (Fjelstul et al., 2011). As the history of golf itself shows, the social representation of the sport was built around the exclusiveness of the social classes, clubs and etiquette: "The frequency of rules regarding etiquette grew on a par with the increasing exclusion of the Scottish lower class from the sport. The early history [of golf] does suggest that there was popular participation in the 18th century, [but] formalisation began to shift it toward being a middle-class preserve” (Lowerson, 1994a, p. 79) (Ceron-Anaya, 2010:344). So it is important to create a new dynamic associated to golf, ensuring it is an "open sport", thus demystifying the elite ideal that it still has, in a certain way, connected to it. By promoting a wider local participation in golf, we are strongly contributing to ensure a better golf sustainability. Besides the environmental dimension, the socioeconomic is all so vital for golf destinations sustainable development, considering that the balance between leisure golf demand and tourism golf demand is critical for a consistent golf industry development. Without this demand stability, golf courses and the golf industry in a general, cannot reach the desires levels of economic efficiency, disabling its contribution to the local economy and so, to the local development.

For golf destinations as Portugal (as similar ones, for example in the southern Europe), this should be a priority issue for golf development, considering the high level of golf supply, mainly sustained on international golf tourists, and the low level of leisure golf demand (resident golf players). In this cases golf destinations are at risk, because its life cycle is anaemic i.e., golf demand life cycle is not running along with the golf supply, because leisure golf demand is low.

\section{References}

Briassoulis, H. (2010). Sorry Golfers, This Is Not Your Spot!: Exploring Public Opposition to Golf Development. Journal of Sport \& Social Issues, 34(3), 288-311. http://dx.doi.org/10.1177/0193723510377314

Bull, C. (2005). Sport tourism destination resource analysis. In Higham, J. (Ed.), Sport Tourism Destinations - Issues, opportunities and analysis (pp. 25-38). Oxford: Elsevier Butterworth-Heinemann.

Ceron-Anaya, H. (2010). An Approach to the History of Golf: Business, Symbolic Capital, and Technologies of the Self. Journal of Sport and Social Issues, 34, 339-358. http://dx.doi.org/10.1177/0193723510377317

EGA (European Golf Association). (2013). Statitics by Country-Portugal. Retrieved from http://www.ega-golf.ch/050000/050331.asp 
Elkington, J., \& Hartigan, P. (2008). The Power of Unreasonable People: How Social Entrepreneurs Create Markets That Change the World. Watertown: Harvard Business Review Press.

Fjelstul, J., Jackson, L., \& Tesone, D. (2011). Increasing Minority Golf Participation Through PGA Education Initiatives. Sage Open, 2, 1-5. http://dx.doi.org/10.1177/2158244011416009.

Hammond, R., \& Hudson, M. (2007). Environmental management of UK golf courses for biodiversity—attitudes and actions. Landscape and Urban Planing, 83(2-3), 127-136. http://dx.doi.org/10.1016/j.landurbplan.2007.03.004

Hatami, D. (2013). Thoughts from the golf industry show (Part 3). Boulder: HVS Golf Services.

Higham, J. (2005). Introduction to Sport Tourism Destination Marketing and Management. In Higham, J. (Ed.) Sport Tourism Destinations-Issues, opportunities and analysis (pp. 53-162). Oxford: Elsevier Butterworth-Heinemann.

Higham, J., \& Hinch, T. (2009). Transnationalism, Migration and Diaspora. In Higham, J., \& Hinch, T. (Eds.), Sport and Tourism-Globalization, Mobility and Identity (pp. 177-198). Oxford: Elsevier Butterworth-Heinemann.

Hudson, S. (Ed.). (2002). Sport and Adventure Tourism. Oxford: The Haworth Hospitality.

Hudson, S., \& Hudson, L. (2010). Golf Tourism. Oxford: Goodfellow Publishers Limited.

Knowles, T., Diamantis, D., \& El-Mouhabi, J. (2004). The Globalization of Tourism \& Hospitality. London: Thomson.

KPMG. (2008). The economic value of golf to Europe. Retrieved from http://www.egcoa.eu/bestanden/pics/The\%20Economic\%20Value\%20of\%20Golf\%20to\%20Europe_28082 009\%20(2).pdf

KPMG. (2010). The Business of Profissional Tournament Golf. Retrieved from http://www.kpmg.com/DK/da/nyheder-og-indsigt/nyhedsbreve-og-publikationer/publikationer/advisory/gen erelle-publikationer/Documents/The\%20Business\%20of\%20Professional\%20Golf.pdf

KPMG. (2011). Golf participation in Europe. Retrieved from www.golfbusinesscommunity.com/.../golf_participation_in_europe_2010

KPMG. (2012). Golf Travel Insights 2012. Retrieved from https://static.golfbusinesscommunity.com/media/1/9/6/1/1961.pdf

Markwick, M. (2000). Golf tourism development, stakeholders, differing discourses and alternative agendas: the case of Malta. Tourism Management, 21, 515-524. http://dx.doi.org/10.1016/S0261-5177(99)00107-7

MEI (Ministério da Economia e Inovação Portugal). (2007). Plano Estratégico Nacional do Turismo-para o desenvolvimento do turismo em Portugal. Lisboa: Turismo de Portugal.

Minolia, D., \& Smith, M. (2011). An exploration of golf and voluntary environmental programmes. Journal of Environmental Planning and Management, 54(7), 871-889. http://dx.doi.org/10.1080/09640568.2010.539372

Moital, M., Dias, N., \& Machado, D. (2013). A cross national study of golf tourists' satisfaction. Journal of Destination Marketing \& Management, 2(1), 39-45. http://dx.doi.org/10.1016/j.jdmm.2013.02.003

Neirotti, L. (2005). Sport tourism markets. In Higham, J. (Ed.), Sport Tourism Destinations-Issues, opportunities and analysis (pp. 36-56). Oxford: Elsevier Butterworth-Heinemann.

Nice, B. (2004). Golf in meetings, incentives, conventions, exhibitions (mice) tourism: perceptions of meeting $\begin{array}{llll}\text { planners } & \text { (Master's thesis). } & \text { Retrieved }\end{array}$ http://ufdcimages.uflib.ufl.edu/UF/E0/00/69/82/00001/nice_b.pdf

Pedro, A. (2006). Urbanization and Second Home Tourism. In Buhalis, D., \& Costa, C. (Eds.), Tourism Business Frontiers-Consumers, Products and Industry (pp. 85-93). Oxford: Elsevier Butterworth-Heinemann.

Perkins, C. (2010). The Performance of Golf: Landscape, Place, and Practice in North West England. Journal of Sport and Social Issues, 34, 312-338. http://dx.doi.org/10.1177/0193723510377316.

Potoski1, M., \& Prakash, A. (2013). Green Clubs: Collective Action and Voluntary Environmental Programs. The Annual Review of Political Science, 16. http://dx.doi.org/10.1146/annurev-polisci-032211-211224 
Readman, M. (2003). Golf Tourism. In Hudson, S. (Ed.), Sport and Adventure Tourism (pp. 165-202). London: Haworth Hospitality Press.

Shao, X., Mao, Z., \& Chen, X. (2012). Reflection on Golf Education Development in China under Leisure Sports Perspective. Education Management, Education Theory and Education Application Advances in Intelligent and Soft Computing, 109, 689-695. http://dx.doi.org/10.1007/978-3-642-24772-9_100

UNTWO (United Nations World Tourism Organization). (2001). Tourism Visions 2020. Madrid: UNTWO.

Vamplew, W. (2010). Sharing Space: Inclusion, Exclusion, and Accommodation at the British Golf Club Before 1914. Journal of Sport and Social Issues, 34(3), 359-375. http://dx.doi.org/10.1177/0193723510377327

Videira, N., Correia, A., Alves, I., Subtil, R., \& Martins, V. (2006). Environmental and Economic Tools to Support Sustainable Golf Tourism: The Algarve Experience, Portugal. Tourism and Hospitality Research, 6(3), 204-217. http://dx.doi.org/10.1057/palgrave.thr.6050013.

Wood, C., Dipper, B., \& Jones, C. (2000). Auditing the Assessment of the Environmental Impacts of Planning Projects. Journal of Environmental Planning and Management, 43(1), 23-47. http://dx.doi.org/10.1080/09640560010757

\section{Copyrights}

Copyright for this article is retained by the author(s), with first publication rights granted to the journal.

This is an open-access article distributed under the terms and conditions of the Creative Commons Attribution license (http://creativecommons.org/licenses/by/3.0/). 